\title{
Primary prophylaxis of variceal bleeding
}

\author{
Marcus Robertson $^{1,2} \cdot$ Peter Hayes ${ }^{1}$
}

Received: 23 December 2017 / Accepted: 23 January 2018/Published online: 2 February 2018

(C) Asian Pacific Association for the Study of the Liver 2018

\section{Introduction}

Varices are prevalent in patients with cirrhosis and represent the development of portosystemic collateral vessels as a consequence of portal hypertension. Acute variceal bleeding (AVB) remains a common and life-threatening complication associated with significant morbidity and mortality. Improvements in management along with an expansion in the therapeutic armamentarium have resulted in a significant improvement in the mortality rate associated with an episode of AVB, although this remains around 15-20\% [1]. Thus, variceal bleeding continues to be a leading cause of death in patients with cirrhosis [2].

Gastro-esophageal varices are present in approximately $50 \%$ of patients with cirrhosis at the time of diagnosis (30\% in patients with compensated cirrhosis, rising to $60 \%$ prevalence in patients with decompensated cirrhosis) [3]. 5-10\% of cirrhotic patients will form esophageal varices each year, and once varices have developed they may increase in size at a rate of 5-30\% per year [4]. In patients with established varices, approximately $12 \%$ will have a first variceal hemorrhage within 1 year; this risk increases with large varices, varices with high-risk stigmata and more advanced liver disease. Thus, the presence of varices is common in patients with cirrhosis, although bleeding will ultimately occur in only approximately one-third of patients [5].

Primary prophylaxis of variceal bleeding encompasses strategies which aim to prevent the first episode of AVB in patients with cirrhosis. Currently, two main treatment strategies are widely employed: pharmacological reduction of portal pressures below pathological levels through the introduction of non-selective beta blockers (NSBBs) or

Marcus Robertson

Marcus.Robertson@monashhealth.org.au

1 Department of Hepatology, Royal Infirmary of Edinburgh, Edinburgh, UK

2 Department of Gastroenterology and Hepatology, Monash Health, Melbourne, Australia direct variceal eradication through serial endoscopic variceal ligation (EVL) procedures. Current expert consensus is that NSBBs or EVL have largely equivalent efficacy in preventing AVB; the choice of treatment should be based on individual patient characteristics, local resources and expertise and patient preference [6,7]. Primary prophylaxis is addressed in this journal in the paper by Abd ElRahim et al. [8].

\section{Risk-factors for variceal bleeding}

All patients with cirrhosis should be assessed for the presence of risk-factors that increase the likelihood of AVB, the most significant of which is the size of the esophageal varices. The presence of large varices has been demonstrated to be a major risk factor for the development of variceal hemorrhage; in patients with nearly identical portal hypertension, the likelihood of AVB is markedly increased in patients with large varices. In addition, certain high-risk variceal stigmata, collectively termed "red signs" (red wale markings, cherry red spots, nipple sign, hematocystic spots) have been associated with a significantly increased risk of AVB $[2,5]$. Patients with advanced liver disease (Child-Pugh score C) are also more likely to experience AVB.

In addition, the hepatic venous wedge pressure (HVPG) is a useful clinical marker of portal pressures and correlates with the risk of variceal development and hemorrhage. A HVPG of $12 \mathrm{mmHg}$ (normal $\mathrm{HVPG}<5 \mathrm{mmHg}$ ) is the baseline elevated pressure above which variceal bleeding may occur. Reducing the HVPG below $12 \mathrm{mmHg}$ or by at least $20 \%$ from baseline is associated with significant protection against bleeding [2]. In practice, however, HVPG is rarely measured due to the invasiveness of the test. 


\section{Risk stratification of variceal bleeding in patients with cirrhosis}

It is recommended that all patients with a new diagnosis of cirrhosis be endoscopically screened for the presence and size of varices so that prophylactic therapy can be given to those with varices that are at increased risk of bleeding. Patients with compensated cirrhosis and no varices at index endoscopy should have a repeat gastroscopy every 2-3 years, with the timing influenced by whether the liver injury is ongoing [7]. Patients with compensated cirrhosis and small varices with no high-risk stigmata may be considered for endoscopic variceal surveillance every 1-2 years to evaluate progression. In patients with advanced liver disease or medium or large varices, primary prophylaxis should be implemented.

There is an emerging evidence that some patients may be able to have variceal risk stratification using non-invasive methods, which could obviate the need for endoscopy in some cases. The probability of high-risk varices being present appears to be very low $(<5 \%)$ in patients with compensated cirrhosis with a platelet count $\geq 150,000$ and a liver stiffness (LS) of $<20 \mathrm{kPa}$ on transient elastography (TE) $[6,7]$, although currently this is only validated in patients with hepatitis C. In this patient cohort, one approach may be to perform annual platelet count and TE scans, and perform endoscopic screening for varices if the platelet count drops to $<150,000$ or the LS increases to $\geq 20 \mathrm{kPa}$. More studies are required to validate this method.

\section{Prophylaxis of variceal bleeding}

Primary prophylaxis of AVB is recommended in all patients with a high-risk of bleeding. These include:

a. Patients with medium or large varices.

b. Patients with small varices with high-risk stigmata ("red signs").

c. Patients with decompensated cirrhosis (Child-Pugh B or C) regardless of variceal size.

Currently, either NSBB or EVL can be commenced; both modalities are superior to no treatment for the prevention of first AVB [9]. In deciding upon a treatment, the risks and benefits of each treatment must be considered on a case-by-case basis. EVL constitutes an invasive procedure with potential procedure-related complications and requires operator expertise, significant hospital resources and patient time commitments (as multiple procedures are required per patient). Beta blockers have a low risk of serious side-effects, however, a significant proportion of patients with cirrhosis do not tolerate them and there may be a large pill burden. Table 1 summarises the different modalities for primary prophylaxis of variceal bleeding.

In this journal, Abd ElRahim et al. [8]. compared carvedilol, propranolol and EVL for primary prophylaxis of AVB in 264 patients with cirrhosis and high-risk varices. Although the rate of bleeding was equivalent between the treatment groups, the authors concluded that EVL should be the preferred method for primary prophylaxis of AVB given a low complication rate and a higher "success" rate. This conclusion should be interpreted with caution for a number of reasons. Firstly, the definition of treatment "success" differed between patient groups (eradication of varices in the EVL group, but absence of bleeding in the propranolol and carvedilol groups) and thus represents different clinical endpoints. This makes accurate comparisons of treatment efficacy between study groups extremely difficult.

Secondly, the authors conclude that EVL has a superior side-effect profile with the least significant reported sideeffects compared to NSBB's. It is important to note, however, that 4 of the $9(44 \%)$ acute variceal bleeding episodes occurring in the EVL group were the result of post-banding ulcers, which represent a serious and lifethreatening treatment complication. In addition, the dose of carvedilol prescribed in this study often exceeded $12.5 \mathrm{mg}$ per day, which may have contributed to a higher side-effect profile in this treatment group. Guidelines suggest that Carvedilol should not be prescribed at a dose exceeding $12.5 \mathrm{mg}$ daily; higher doses are associated with an increased rate of complications such as hypotension with no extra decrease in portal pressures.

Finally, there appear to be significant flaws in the randomisation and treatment allocation process. Patients in whom beta blockers were contraindicated were routinely allocated to the EVL treatment arm and thus the groups cannot be considered to be truly randomised. Despite this, at the end of the allocation process identical numbers of patients were allotted to each of the three study groups which again raise questions about the randomisation and treatment allocation procedures, which are not detailed in the manuscript. Furthermore, a high number of patients were either excluded or dropped-out of the study following treatment allocation, however, no intention-to-treat analysis was performed which increases the possibility of attrition bias in the results.

Overall, these limitations in study design make accurate comparison of efficacy between propranolol, carvedilol and EVL in primary prophylaxis of AVB very difficult and limit the study's applicability. 
Table 1 Treatment options for primary prophylaxis of variceal bleeding [6]

\begin{tabular}{|c|c|c|c|c|c|}
\hline Therapy & $\begin{array}{l}\text { Recommended } \\
\text { dose }\end{array}$ & Important targets & Advantages & Disadvantages & Follow-up \\
\hline Propranolol & $\begin{array}{l}20-40 \mathrm{mg} \\
\text { orally BD } \\
\text { Maximal daily } \\
\text { dose: } \\
320 \mathrm{mg} / \text { day in } \\
\text { patients } \\
\text { without } \\
\text { ascites } \\
160 \mathrm{mg} / \text { day in } \\
\text { patients with } \\
\text { ascites }\end{array}$ & $\begin{array}{l}\text { Aim for a } 25 \% \\
\text { reduction in } \mathrm{HR} \text { or a } \\
\text { resting } \mathrm{HR} \text { of } \\
55-60 \mathrm{bpm} \\
\text { sBP should not } \\
\text { decrease }<90 \mathrm{mmHg} \\
\text { Adjust dose every } \\
2-3 \text { days until } \\
\text { treatment goal is } \\
\text { achieved }\end{array}$ & $\begin{array}{l}\text { Cheap } \\
\text { Non-invasive } \\
\text { May also decrease the risk of } \\
\text { developing ascites or SBP by } \\
\text { reducing portal pressure and } \\
\text { decreasing bacterial } \\
\text { translocation }\end{array}$ & $\begin{array}{l}\text { High pill burden } \\
\text { which may affect } \\
\text { compliance } \\
\text { Need to cease in the } \\
\text { event of } \\
\text { decompensation } \\
\text { including SBP } \\
\text { Can be poorly } \\
\text { tolerated } \\
\text { Contraindicated in } \\
\text { asthma, PVD, } \\
\text { bradycardia }\end{array}$ & $\begin{array}{l}\text { Medication should be } \\
\text { continued indefinitely } \\
\text { Ensure patient's HR } \\
\text { remains on target }\end{array}$ \\
\hline Nadolol & $\begin{array}{l}20-40 \mathrm{mg} \\
\text { orally BD } \\
\text { Maximal daily } \\
\text { dose: } \\
160 \mathrm{mg} / \text { day in } \\
\text { patients } \\
\text { without } \\
\text { ascites } \\
80 \mathrm{mg} / \text { day in } \\
\text { patients with } \\
\text { ascites }\end{array}$ & $\begin{array}{l}\text { Aim for a } 25 \% \\
\text { reduction in } \mathrm{HR} \text { or a } \\
\text { resting } \mathrm{HR} \text { of } \\
55-60 \mathrm{bpm} \\
\text { sBP should not } \\
\text { decrease }<90 \mathrm{mmHg} \\
\text { Adjust dose every } \\
2-3 \text { days until } \\
\text { treatment goal is } \\
\text { achieved }\end{array}$ & $\begin{array}{l}\text { Cheap } \\
\text { Non-invasive } \\
\text { May also decrease the risk of } \\
\text { developing ascites or SBP by } \\
\text { reducing portal pressure and } \\
\text { decreasing bacterial } \\
\text { translocation }\end{array}$ & $\begin{array}{l}\text { High pill burden } \\
\text { which may affect } \\
\text { compliance } \\
\text { Need to cease in the } \\
\text { event of } \\
\text { decompensation } \\
\text { including SBP } \\
\text { Can be poorly } \\
\text { tolerated } \\
\text { Contraindicated in } \\
\text { asthma, PVD, } \\
\text { bradycardia }\end{array}$ & $\begin{array}{l}\text { Medication should be } \\
\text { continued indefinitely } \\
\text { Ensure patient's HR } \\
\text { remains on target }\end{array}$ \\
\hline Carvedilol & $\begin{array}{l}\text { Starting dose } \\
6.25 \mathrm{mg} \text { once } \\
\text { daily } \\
\text { Maximal dose } \\
12.5 \mathrm{mg} \text { daily }\end{array}$ & $\begin{array}{l}\text { sBP should not } \\
\text { decrease }<90 \mathrm{mmHg} \\
\text { Aim to increase dose } \\
\text { after } 1 \text { week }\end{array}$ & $\begin{array}{l}\text { Lower pill burden than other } \\
\text { NSBBs } \\
\text { May produce a greater decrease } \\
\text { in portal pressures than other } \\
\text { NSBBs }\end{array}$ & $\begin{array}{l}\text { Need to cease in the } \\
\text { event of } \\
\text { decompensation } \\
\text { including SBP } \\
\text { Can be poorly } \\
\text { tolerated } \\
\text { Contraindicated in } \\
\text { asthma, PVD, } \\
\text { bradycardia }\end{array}$ & $\begin{array}{l}\text { Medication should be } \\
\text { continued indefinitely }\end{array}$ \\
\hline EVL & $\begin{array}{l}\text { Every } \\
2-8 \text { weeks } \\
\text { until variceal } \\
\text { eradication }\end{array}$ & $\begin{array}{l}\text { Variceal eradication } \\
\text { (no further ligation } \\
\text { possible) }\end{array}$ & $\begin{array}{l}\text { Does not require daily } \\
\text { medications } \\
\text { May reduce risk of AVB more } \\
\text { than NSBB } \\
\text { Generally well tolerated }\end{array}$ & $\begin{array}{l}\text { High cost } \\
\text { Large time } \\
\text { commitment for } \\
\text { patient } \\
\text { Pain following } \\
\text { procedure } \\
\text { common } \\
\text { Requires operator } \\
\text { expertise } \\
\text { Procedure-related } \\
\text { complications } \\
\text { (aspiration, } \\
\text { banding ulcers, } \\
\text { stricture } \\
\text { formation) } \\
\text { Varices can recur }\end{array}$ & $\begin{array}{l}\text { Surveillance endoscopy } \\
\text { should be performed } \\
3-6 \text { months following } \\
\text { successful eradication and } \\
\text { every } 6-12 \text { months } \\
\text { thereafter }\end{array}$ \\
\hline
\end{tabular}

$H R$ heart rate, $s B P$ systolic blood pressure, $b p m$ beats per minute, $S B P$ spontaneous bacterial peritonitis, $P V D$ peripheral vascular disease 


\section{Prophylaxis with non-selective beta blockers}

NSBB have been widely used and extensively studied in the primary prevention of AVB and remain a cornerstone of prophylaxis. NSBB aim to decrease portal pressures (ideally to below pathological levels) by cardiac output reduction and splanchnic arterial constriction which ultimately leads to decreased portal venous inflow.

Multiple studies have demonstrated the efficacy of NSBBs in preventing AVB. Hayes et al. performed a metaanalysis of seven trials with 797 patients and found that patients treated with NSBB had lower bleeding rates (12 vs. $23 \%$ ), fewer deaths due to bleeding (5 vs. 10\%) and a trend toward a lower overall mortality rate ( 21 vs. $27 \%$, $p=0.052$ ) [10]. The most recent meta-analysis to compare NSBBs with placebo demonstrated a significant benefit of NSBBs in preventing first variceal bleeding (15 vs. 24\%) after 2 years [11]. The number of patients needed to treat to prevent one variceal bleeding episode was 10. Patients receiving NSBBs were also noted to have a lower mortality rate (23.9 vs. $28.4 \%)$. NSBBs may also impact the progression of portal hypertension in patients with small varices, with studies suggesting a reduction in progression to large varices, although no survival benefit was observed [12].

Propranolol or Nadolol have traditionally been the most widely used NSBBs for primary prophylaxis. In either case, the dose should be titrated to either a resting heart-rate of 55-60 beats per minute, the maximal dose or the development of side-effects. Lower heart rates should be avoided due to the emergence of side-effects.

More recently, studies have shown Carvedilol, a nonselective beta blocker with intrinsic $\alpha 1$-adrenergic activity, to produce a greater decrease in portal pressure compared to propranolol [13]. Two trials also compared Carvedilol to EVL, finding either a greater [14] or equivocal [15] efficacy of carvedilol. Reiberger et al. demonstrated that $56 \%$ patients who failed to achieve an adequate reduction in HVPG with propranolol achieved a response with Carvedilol, with remaining patients undergoing EVL. Patients receiving Carvedilol were found to have a significant reduction in bleeding rate, hepatic decompensation and death compared to patients receiving EVL [16]. Thus, Carvedilol (6.25 mg increasing to $12.5 \mathrm{mg}$ oral daily) should be considered a first-line agent in the primary prophylaxis of AVB. Doses higher than $12.5 \mathrm{mg}$ should not be given as these result in a further decrease in blood pressure without additional reduction in HVPG.

Once treatment with NSBBs is initiated it is generally continued lifelong as bleeding risk returns to baseline if the treatment is ceased. Beta blockers may also decrease the risk developing of ascites, spontaneous bacterial peritonitis and portal hypertensive gastropathy bleeding [9]. Around $15 \%$ of patients may have contraindications to NSBBs (such as reactive airway disease, congestive heart failure, bradycardia or heart block) and a further $15 \%$ require dose reduction or discontinuation due to common side-effects (fatigue, weakness, shortness of breath) [6]; in these cases patients can be switched to Carvedilol or EVL can be instituted.

\section{Prophylaxis with endoscopic variceal ligation (EVL)}

EVL is the preferred method for endoscopic prevention of AVB and involves serial episodes of variceal banding until esophageal varices are eradicated; this typically takes 4-6 procedures. A meta-analysis of 8 RCTs comparing EVL to no treatment demonstrated that EVL was superior in reducing both the risk of first AVB and mortality [17]. Multiple studies have also compared the efficacy of EVL to NSBB. A Cochrane review of 19 RCTs published in 2012 demonstrated that EVL was associated with significantly lower rates of both upper gastrointestinal bleeding (14 vs. $20 \%$ ) and AVB (13 vs. 19\%), although the beneficial effect of EVL was not confirmed in a sub-group analysis of trials with adequate randomisation or fully published studies. In addition, no difference in mortality was noted between the EVL and NSBB groups [18].

Advantages of EVL include: the potential ability to treat varices in the same session as screening endoscopy; avoiding the need to take medications up to twice daily, and; few contraindications to the procedure. Disadvantages include: the need for operator experience in EVL; procedure-related complications (sedation risks, post-procedural pain and/or dysphagia, esophageal ulcers, strictures and bleeding); the high costs associated with multiple procedures, and; significant time commitments from patients [6]. Although rare, there is a potential risk of serious adverse outcomes from EVL, including deaths from bleeding ulcers secondary to EVL [12].

Primary prophylaxis using combination NSBB and EVL is not recommended. Sarin et al. investigated the addition of propranolol to EVL and found no decrease in the probability of first bleeding or death but an increased rate of side-effects [19].

\section{Conclusion}

All patients with cirrhosis should be screened for the presence of varices, and primary prophylaxis commenced in those with medium or large varices, high-risk stigmata or advanced liver disease. Current guidelines recommend 
that NSBBs and EVL have equivalent efficacy in preventing AVB. Generally, NSBBs are considered first-line, with EVL reserved for patients who are intolerant and patients with large varices. The choice of treatment should be based on individual patient characteristics, local resources and expertise and patient preference.

\section{Compliance with ethical standards}

Conflict of interest Marcus Robertson and Peter Hayes declare that they have no conflict of interest.

\section{References}

1. Carbonell N, Pauwels A, Serfaty L, Fourdan O, Lévy VG, Poupon R. Improved survival after variceal bleeding in patients with cirrhosis over the past two decades. Hepatology 2004;40(3):652-659.

2. Robertson M, Hayes P. Management of acute variceal bleeding. In: Plevris JN, Hayes PC, Kamath PS, Wong Kee Song LM, editors. Endoscopy in liver disease. Oxford: Wiley; 2018.

3. D'Amico G, Luca A. Natural history. Clinical-haemodynamic correlations. Prediction of the risk of bleeding. Baillieres Clin Gastroenterol 1997;11(2):243-256.

4. Merli M, Nicolini G, Angeloni S, Rinaldi V, De Santis A, Merkel $\mathrm{C}$, et al. Incidence and natural history of small esophageal varices in cirrhotic patients. J Hepatol 2003;38(3):266-272.

5. North Italian Endoscopic Club for the Study and Treatment of Esophageal Varices. Prediction of the first variceal hemorrhage in patients with cirrhosis of the liver and esophageal varices. N Engl J Med 1988;319(15):983-989.

6. Garcia-Tsao G, Abraldes JG, Berzigotti A, Bosch J. Portal hypertensive bleeding in cirrhosis: risk stratification, diagnosis, and management: 2016 practice guidance by the American Association for the study of liver diseases. Hepatology 2017;65(1):310-335.

7. de Franchis R. EXPANDING consensus in portal hypertension report of the Baveno VI consensus workshop: stratifying risk and individualizing care for portal hypertension. J Hepatol 2015;63(3):743-752.
8. Abd ElRahim AY, Fouad R, Khairy M, Elsharkawy A, Fathalah W, Khatamish H, et al. Efficacy of carvedilol versus propranolol versus variceal band ligation for primary prevention of variceal bleeding. Hepatol Int 2018. https://doi.org/10.1007/s12072-0179835-9 (epub ahead of print).

9. Triantos C, Kalafateli M. Primary prevention of bleeding from esophageal varices in patients with liver cirrhosis. World $\mathrm{J}$ Hepatol 2014;6(6):363-369.

10. Hayes PC, Davis JM, Lewis JA, Bouchier IA. Meta-analysis of value of propranolol in prevention of variceal haemorrhage. Lancet 1990;336(8708):153-156.

11. D'Amico G, Pagliaro L, Bosch J. Pharmacological treatment of portal hypertension: an evidence-based approach. Semin Liver Dis 1999;19(4):475-505.

12. Karadsheh Z, Allison H. Primary prevention of variceal bleeding: pharmacological therapy versus endoscopic banding. N Am J Med Sci 2013;5(10):573-579.

13. Bañares R, Moitinho E, Matilla A, García-Pagán JC, Lampreave $\mathrm{JL}$, Piera $\mathrm{C}$, et al. Randomized comparison of long-term carvedilol and propranolol administration in the treatment of portal hypertension in cirrhosis. Hepatology 2002;36(6):1367-1373.

14. Tripathi D, Ferguson JW, Kochar N, Leithead JA, Therapondos G, Mcavoy NC, et al. Randomized controlled trial of carvedilol versus variceal band ligation for the prevention of the first variceal bleed. Hepatology 2009;50(3):825-833.

15. Shah HA, Azam Z, Rauf J, Abid S, Hamid S, Jafri W, et al. Carvedilol vs. esophageal variceal band ligation in the primary prophylaxis of variceal hemorrhage: a multicentre randomized controlled trial. J Hepatol 2014;60(4):757-764.

16. Reiberger T, Ulbrich G, Ferlitsch A, Payer BA, Schwabl P, Pinter $\mathrm{M}$, et al. Carvedilol for primary prophylaxis of variceal bleeding in cirrhotic patients with haemodynamic non-response to propranolol. Gut 2013;62(11):1634-1641.

17. Imperiale $T$, Chalasani N. A meta-analysis of endoscopic variceal ligation for primary prophylaxis of esophageal variceal bleeding. Hepatology 2001;33(4):802-807.

18. Gluud LL, Krag A. Banding ligation versus beta-blockers for primary prevention in oesophageal varices in adults. In: Gluud LL, editor. Cochrane database of systematic reviews. Chichester: Wiley; 2012. p. CD004544.

19. Sarin SK, Wadhawan M, Agarwal SR, Tyagi P, Sharma BC. Endoscopic variceal ligation plus propranolol versus endoscopic variceal ligation alone in primary prophylaxis of variceal bleeding. Am J Gastroenterol 2005;100(4):797-804. 